\title{
Particle Image Velocimetry の展開*
}

小林 敏雄 ${ }^{* *}$, 岡本 “孝司 ${ }^{* * *}$, 佐賀 徹雄 ${ }^{\dagger}$

\section{Innovation of Particle Image Velocimetry}

\author{
Toshio Kobayashi, Koji Okamoto and Tetsuo Saga
}

\section{1.はじめに}

流れを知ることは，工学の最も基礎的な知見である。 煙突から流れ出る煙を見ると大気の流れを知ることがで きるが，流れそのものは普通は目に見えない，煙突の煙 は，目に見えない流れを可視化するためのトレーサーで ある. 透明な空気や水の流れが，トレーサーの動きを通 して人間の理解できる画像として映し出されている．有 名なレオナルド・ダ・ビンチのスケッチや，鴨長明の方 丈記を見るまでもなく，絵（眼）によって定性的な流れ の動きを知る事は，遥か昔から行われて来ている，現在 の製品開発の現場においても，流れの可視化技術は広く 用いられている.

近年のデジタル処理技術の格段の進歩により，これら の定性的な流机の可視化画像デー夕から，定量的な情報 を抽出する事が出来るようになって来ている。この定量 可視化工学の最も代表的な例が, 粒子画像流速測定法 (Particle Image Velocimetry：PIV) ${ }^{12}$ と呼ばれる流速分 布の計測法である。この 10 年で PIV は大きく進歩し, 様々な流れ場における一般的な流速計測法として，その 地位を確立して来ている。

PIV の大きな特徽は，分布が計測できる事である．画 像は 2 次元の情報を持っている. 可視化された 2 次元画 像に記録されている画像情報を解析することで，定量物 理量（流速）を計測するということは，3 次元空間中の 2 次元分布を計測するということである。これは，従来 のピトー管やレーザードップラ流速計（LDV）とは大 きく異なる点である．さらに，ハードウェアやソフトウ エアの進歩とあいまって, 高解像度の流速分布情報や, 時間方向にも密な情報（過渡変化）を取得することが可 能となって来ている。

本稿では, 特にここ $2 \sim 3$ 年のハードウエア, ソフト ウエアの進歩をレビューするとともに, PIVによって培 われた技術を, 流速以外の物理量計測手法への応用や, 全く異る分野への応用など, PIV の展開について考えて

\footnotetext{
* 原稿受付 2000 年 1 月 5 日

** 正会貣 東京大学 国際・産学共同研究センター

*** 正会貝 東京大学 大学院工学系研究科

$\dagger$ 正会員 東京大学 生産技術研究所
}

いきたい。

\section{2 . 2 次元 2 成分流速計測}

画像は 2 次元情報である。これに対して，流れ場は 3 次元空間 +1 次元時間の情報量を持っている. 2 次元画 像は, 4 次元時空間の中から, 任意の瞬時 2 次元断面を 切り出したものと考えることができる. この 2 次元断面 の情報は 2 次元画像に情報として記録することが可能で ある。つまり，画像を用いることで，2次元断面情報を 固定化できる。この 2 次元断面情報を 2 時刻に渡って取 得し，その画像間の変動を抽出すれ代断面内の速度べク トル（2成分ベクトル）に換算できる.

この 2 次元 2 成分流速計測に関しては, PIV は実用化 の域に近付いている. 計測できる領域の大きさは, 数 $\mathrm{cm}$ から $1 \mathrm{~m}$ 程度の大きさの領域に限られているが, 数 $\mathrm{mm}$ /s から数百 $\mathrm{m} / \mathrm{s}$ といった高速流まで，扔金をかけれ ばほぼターンキーシステムに近い形で計測を行うことが 出来る。これは，以下に述べるようにハードウエアが大 きく進歩して来たことが大きい。これに対し，ソフトウ エア側も，コンピュータの大容量化高速化を受けて，時 間が掛かっても画像の持っている全ての情報を抽出しょ うとするアルゴリズムの開発が盛んである.

前述のように, PIV はいくつかのステップにより成り 立っている．Fig. 1 に概略を示すが，まず，流れ場に粒 子を混入することにより流れ場を可視化しなければなら ない. 次にこの流れ場をカメラなどの機器で撮影しデジ タル化する．最後にこのデジタル画像を解析して流速分 布を算出すると言うステップを取ることとなる。このい くつかの複合システムのどれもが, 精度の良い優れたシ ステムであることが要求される.

\section{1 ハードウエアの進歩}

照明光源 前述のように, 3 次元流れ場を 2 次元画像 によって精度良く取得するためには，対象となる 3 次元 流場の中から 2 次元情報を切り出してやる必要がある. 一般に 2 次元情報を切り出すためにシート光源が用いら れる. シート光源としてはレーザーをシート状にした光 源が輝度も強く, またコントロールが容易なため良く用 いられている．時間軸方向の動きを考えると，ある瞬間 の情報を凍結するためには，照明を短時間に照射するか， 


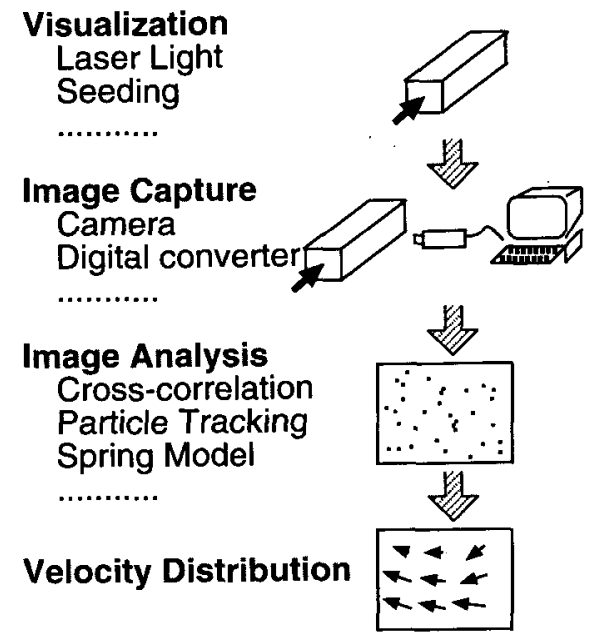

Fig. 1 Flowchart of PIV system

カメラのシャッターを短時間開放するかのどちらかの方 法が必要である。現在主流になりつつある力法は短時間 照明の方式である。シャッターによる時間切り出しの場 合，シャッターが閉じている時間の光は利用されない。 このため短時間を切り出す場合には非常に強力な照明が 必要となってしまう。一方，パルスレーザーを使うこと で瞬時に大量の照明光を発生することが可能であり，こ れが時間切り出しの強力な武器となっている.

この样なパルス照明に使われるレーザーは Nd: YAG レーザーの倍波 $(532 \mathrm{~nm})$ が一般的である. $20 \mathrm{~mJ} \sim 400$ $\mathrm{mJ}$ という強力な光を $10 \mathrm{~ns}$ という短い時間発光する. この時間は流れにとっては十分短いので，瞬間の情報を 凍結することに相当する：このパルスレーザーを 2 本使 うことによって任意の時間間隔の 2 枚の画像を得ること ができるようになる．遅い流れ場ではこの時間間隔を長 くし，速い流れ場では時間間隔を短く（1 소 以下）設定 することで，2つの画像上における粒子の移動距離をコ ントロールすることができる，このため，正確な移動追 跡を行うことができるようになり，近年のPIVは大き く発展した。

現在, この様なパルスレーザーは数百万円している. 数年前は一千万円以上していた事を考えると大幅な下落 である，今後，ダイオードレーザーなどの発達によって， 瞬間的なパルス光源としてのレーザー光が更に安価に得 られることができると期待される．現在のレーザー光源 はヘッドの大きさが $30 \mathrm{~cm}$ 程度で, 一般的な照明器具 程度の大きさまで小さくなって来ている，細かい領域や 複雑な領域の照明を簡易に行うためには，さらなる小型 化や光ファイバーの開発が必要であろう. 現在の光ファ イバでは，パルスレーザー光が強力過ざるため光を通す ことが出来ない。パルス継続時間が $1 \mu s$ 程度の色素レー ザーを用いて光ファイバによる照明を行うことも考えら れているが色素レーザーが高価なためあまり普及してい ない.

トレーサ 流れの可視化画像を得るためには, 照明光
源も重要であるが，可視化するために混入する粒子（ト レーサ）の選択も重要である．画像に記録されるのは粒 子の情報であるので，粒子の動きが流れの動きを代表し ていることが計測の前提となる．強い速度変化がある場 合など，粒子と流れとの間に相対速度を持つことがあり 得る. 粒子が十分小さければ, 流れとの相対速度は十分 小さくなる，しかし，散乱光も弱くなるため，照明シス テム，画像記録システムも含めた最適な粒子の選択が重 要である。

粒子の大きさの他に, 流体と密度が等しいことも重要 となる，浮力／重力の影笠は粒子が十分小さくなれば無 視することが出来るが，加速度への追従性などの問題も あり様々な检討がなされている2,3).気体中へのトレーサ としては，ラスキンノズルによる直径 $1 \mu m$ 程度のオイ ル粒子が用いられることが多い゙.

画像取得装置 照明された領域内の粒子による散乱光 をデジタル画像データとして記録する．画像記録素子と しては，CCD (Charge Coupled Device) が一般的に用 いられている。これは，光量に応じて電荷が蓄えられる 素子であり，一般の家庭用ビデオカメラにも用いられて いる. 最近の CCD 技術の進歩により，高解像度 CCD 素子が製作されている。

任意の時間間隔で発光する 2 つレーザー照明による 2 時刻の画像を各々別々の画像として記録することが重 要である。一つの画像に2 時刻の情報を記録する事は容 易であるが，自己相関法を用いる必要があったり，記録 できる情報が相対的に隇少するなどデメリットも多い. このため 2 枚の連続するビデオ画像の区切りを利用する。 つまり，区切りの直前に 1 時刻目の発光，直後に 2 時刻 目の発光を行うことで，2枚の画像にそれぞれの時刻の 画像を記録するという事が行われる。(フレームストラ ドリングなどと呼ばれる)、レーザーの発光とカメラの 画像取得をコントロールすることで，時間と空間をコン トロールした，情報量の十分な，かつ，精度の高い画像 を得ることができる.情報量の十分な高精度画像は, PIV で得られるべクトルの精度と情報を規定する．これらの ハードウエアによって PIV 技術の信頼性が大幅に高 まったといっても過言ではない，

PIV 画像取得に用いられているCCDカメラとして は, $640 \times 480$ 画素 $/ 60 \mathrm{~Hz}$ のプログレッシブスキャンカ メラ (Sony XC-7500等) や, $1016 \times 1008$ 画素 $/ 30 \mathrm{~Hz}$ の高解像度カメラ (Kodak ES-1.0 等) が用いられてい る. 解像度が大きくなる（画素数が増える）事で, 得ら れる情報量が増大する．また，流れの緗かい変動もとら えることが出来るようになる。

しかし, 低解像度のカメラは 15 万円程度であるが, 高解像度は一般に 100 万円以上する．近年，価格の低下 が著しく，高解像度カメラが一般的になる事が期待され る。また，昨年， $2000 \times 2000$ 画素 $/ 15 \mathrm{~Hz}$ というカメラ (Kodak ES-4.0) も市販され, 高解像度化への動きも進 
んでいる.

なお，現在 CCD 素子ではなく，MOS素子を使った カメラの開発が進められている. MOS 素子は製造工程 がCCD 素子よりも容易であるため, 今後急速にCCD 素子に取って変わることが予想される。しかしながら， MOS 素子は CCD 素子と異なり，光蓄積時間が画像全 体で同一タイミングではない，つまり，現状ではフレー ムストラドリングをMOS 素子で行うことは出来ない.

画像圧縮 時間方向に長時間の画像を取得する場合， 画像データの記録が必要になる. RAM-Busメモリなど コンピュータハードウェアが進歩していくことを考える と, 将来的には画像圧縮なしに画像記録が可能となるこ とも考えられるが, 現状では画像圧縮技術は重要である。 近年の圧縮では不可逆圧縮が主流であり，PIV 画像に対 しても画像圧縮を考虑することは必要であろう。

一般にPIV 画像の持っている情報量は, 画像が最大 保持できる情報量に比較して格段に少ない。このため, $1 / 5$ 程度の画像圧縮（DV）では，粒子情報はほとんど 失われない。つまり，民生分野で広く利用されているデ ジタル圧縮技術をそのまま画像取得に用いることが出来 る. 今後, デジタル圧縮技術はどんどん進歩していくと 予想され，これらの技術を取り入れていくことは重要な ファクターであると考えられる. 現在, $1000 \times 1000$ 程 度の高解像度画像圧縮技術に対する標準化が推進されて おり, 近い将来民生用機器として普及していく可能性が 高い ${ }^{5,6)}$. 但し，注意しなくてはいけないことは，民生用 の画像圧縮技術は人間の目によって圧縮による少化を判 断している事である，つまり，劣化が激しくても人間が 気付かない少化であれば，それを許容すると言うことで ある. 例えば, 現在パーフェク TVなどで使われている MPEG 2 や Motion-JPEG という圧縮方法は，1３0 秒程 度の短時間であれば，全く原画と異る程劣化した画像で も許容している。一方,この様な画像は, 計測には全く 用いることが出来ない. 1 枚 1 枚を別々に圧縮する， JPEG D DVといった正縮技術であればPIVに用いるこ とも可能である.なお, DV ビデオカメラは現在 20 万 円弱で市販されている。このカメラを用いれば，解像度 は $720 \times 240$ と悪くなるが, 1 時間のデータが名刺サイ ズのビデオテープに記録することが可能となっている.

\section{2 ソフトゥエアの進歩}

PIVのアルゴリズム自体はさほど難しいことをやって いるわけではない。現在, 最も広く利用されている手法 は画像相関法である．短時間に撮影された 2 枚の画像を 解析し，画像の歪みを解析して速度分布を求めることに なる，相互相関法の他に，画像中から粒子の重心位置を 算出しその後その重心の移動を解析する手法 (PTV) も 多く利用されている.

相関法 2 台の Nd: YAGパルスレーザーと高解像度 カメラによるフレームストラドリングを行うシステムに おいては，相関法が用いられる。これは，2つの画像の
輝度分布パターンが似通っているパターンを相関值を用 いて探查する方法である. 1 時刻目のパターンの輝度分 布を $f(x, y), 2$ 時刻目を $g(x, y)$ とすると，相関值は，

$$
R(p, q)=\frac{\sum f(x+p, y+q) g(x, y)}{\sqrt{\sum f^{2} \sum g^{2}}}
$$

で与えられ，この $R$ が最大となる $(p, q)$ をもってパター ンの移動先とするものである。ここにあるように，並行 移動が仮定されているが，実際の流れ場にはせん断や回 転が含まれており，移動量が大きくなるとこの手法は適 用できない。一方，2画像間の時間間隔が十分に小さけ れば, 歪みによって失われる情報量は小さく, 単純な相 関法を適用する事が出来る、流れ場の状況に依存するが， 画像中の移動量が $2 \sim 3$ 画素（ピクセル）程度の画像で あれば，相互相関法を用いて比較的精度の良い解析が可 能となる。

さらに，相関值ピーク值周辺の分布がガウス分布をし ていると仮定することによって，サブピクセル精度の移 動量を算出することが行われる. 1 次元の場合, 相関 ピーク値を与える移動量を $p$ (整数) とおくと, サブピ クセル移動量は以下の式で求められる.

$$
P=p-\frac{1}{2} \frac{\ln R_{(p+1)}-\ln R_{(p-1)}}{\ln R_{(p+1)}+\ln R_{(p-1)}-2 \ln R_{(p)}}
$$

この方法で, 0.1 ピタセル程度の精度が得られる。つま り，最大移動量が 3 ピクセルであっても，30：1のダイ ナミックレンジの情報を取得することが可能となる4．

なお，画像量子化の影響とガウス分布仮定からのずれ により，上式でサブピクセルを求めるとピークロッキン グと呼ばれる現象がおきる.これは実際の移動量よりも 整数值の方向にずれた值が求まるものである。このため， 得られたベクトルのヒストグラムを取ると Fig. 2 の様に なる、ピークロッキングが起きているかどうかを知るた めにはヒストグラムを見るのが最も容易で確実である. このサブピクセル精度のピークロッキングを回避するた めには粒子像を 3 ピクセル程度に大きく撮影することが 必要である ${ }^{4,7.8)}$.

また，粒子画像に含まれている情報を最大限に利用す るための研究も進められている9,10). Fig. 3 にその概要を 示す。疑似的に解像度を増大するため画像をスプライン 補間する (Fig. 3a)。この補間によって，1000×1000ピ

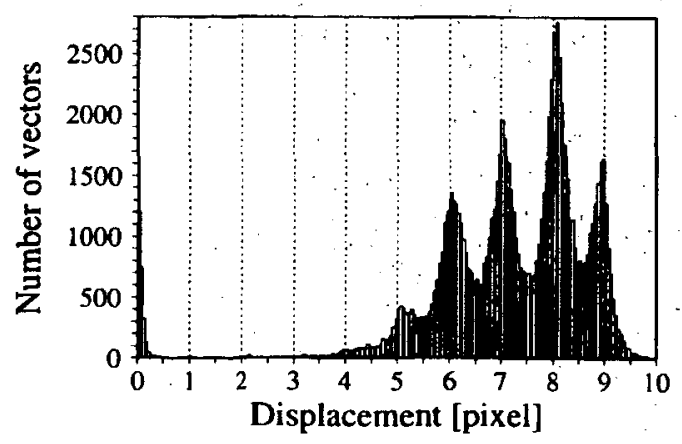

Fig. 2 Histogram of peak-locking vector ${ }^{4 \prime}$ 
クセルの画像を $2000 \times 2000$ ピクセルに増大させること が出来る。これは, 撮影されている画像が粒子であると 言う前提に基ついいている，粒子の画像は比較的緩やかな 変化をしていることから，画像解像度を疑似的に増やす ことが可能となっている、なお，この手法の意味を理論 的に検討した研究は無く，解析によるバックアップが必 要であろう。

次に再帰的相関法もしくは階層的相関法と呼ばれる方 法がある（Fig. 3 b). まず，128×128 といった大きな検 查領域で移動先を求める、これは，大領域の平均的な移 動先であるが, 情報量が十分にあるため, 過誤の少ない データが得られる．次にこれよりも小さな検査領域（例

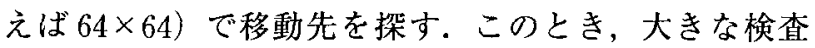
領域で求められた移動先を元にその周辺のみで探查をす る.このことで, 小さな探査領域を高速にから, 過誤の 少ない探査が出来る。この操作を繰り返すことで小さい 検査領域のパターンマッチングを高精度で行うことが可 能となる。つまり，高解像度なべクトルを得ることにな り，1枚の画像から数万点の情報を得ることができる.

Fig. 4 に一例を示すが, 6 万点の情報を取得できている ${ }^{11)}$.

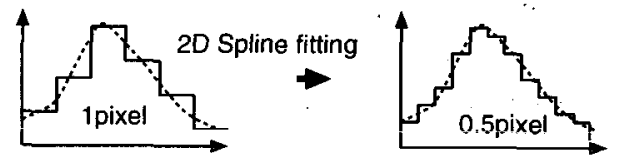

(a) Image Interporation

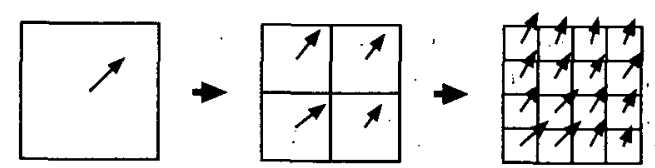

(b) Hierarchical scheme

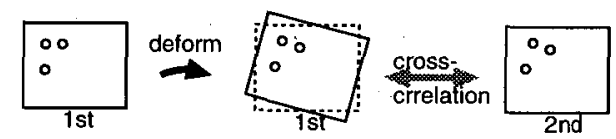

(c) Deformation consideration

Fig. 3 Improved algorithms for PIV analysis ${ }^{9}$

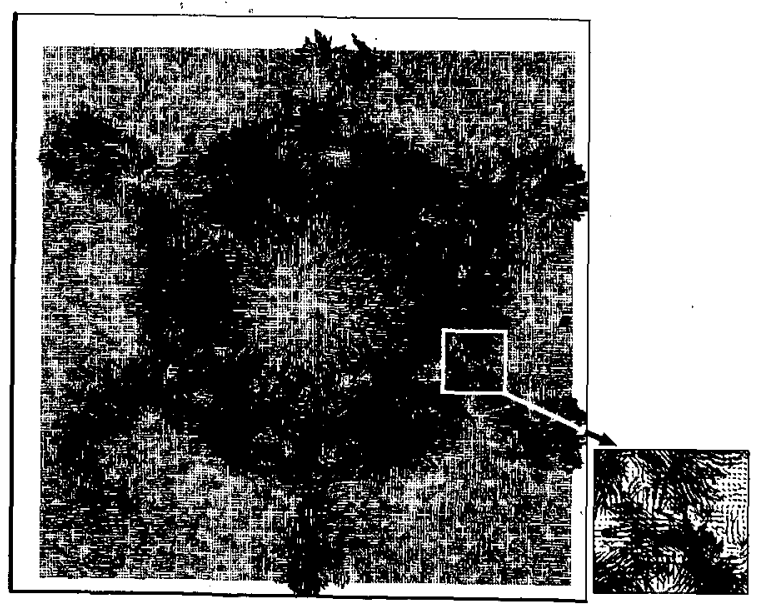

Fig. 4. High resolution PIV $(8 \times 8)^{11}$
さらに，画像歪みを考慮した相関法が挙げられる (Fig. $3 \mathrm{C})$. 再㷌的相関法によって密な流速分布が得ら れると，この流速分布から速度勾配テンソルが得られる。 一方，スプライン補間では任意点（実数点）の輝度值を 求めることが出来る. 速度勾配テンソルを用いて対象領 域の変形を計算し, 変形後の各グリッド位置における輝 度値をスプライン補問して求める。この輝度值と 2 時刻 日の画像輝度值を用いて相関值を求め，これをサブピク セル移動量算出に用いることで，変形を考慮した移動先 が高精度に決定できる。この方法により，0.04ピクセ ルまで精度を高めることができる ${ }^{9)}$.

これらのアルゴリズムの他にも，オプティカルフ ロー ${ }^{122}$ を用いたり，相関法と粒子追跡を組み合わせる方 法 $^{13)}$ ，相関係数を工夫すること ${ }^{14,15)}$ 等で，高解像度の情 報を得ようとする試みがなされている.

なお，相関法の基本アルゴリズム自体は単純であり， フリーソフトウエアもネットワーク上にいろいろと提供

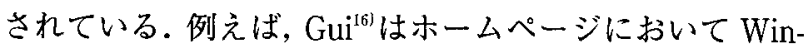
dows 上で動く GUI タイプの PIVソフトウエアを提供 している. また, $\operatorname{Hart}^{17)}$ は, MATLABを用いたフリー のソフトを提供している．PIV 講習会 CD-ROM ${ }^{3 i} に も$ 簡 単なソフトがついている.この様なソフトを利用するこ とも一つの方法であろう。

\section{3．PIV 技術の展開}

PIV を用いた 2 次元流速分布計測は，高解像度，高精 度計測へと進んでいっている. 今後の PIV 技術の展開 としては，3つの方向があると考える。

一つは，標準化および実用化の推進である，例えば， 上記のシステムに最を久けている情報，つまり，精度評 価を行うッールおよび評価標準を設定していく事が挙げ られる。言いかえれば，乱流計測など，2次元空間方向 に十分な精度を持つことを保証するためのシステムの制 定である.ヨーロッパにおいては，EUROPIV（19951997）及びPIVNet（1998-）と呼ばれるプロジェクト が $\mathrm{EC}$ 主体で推進されている ${ }^{18)}$ 。これらは，PIVの開発 と標準化を目指した研究グループで，ヨーロッパにおけ るPIVの普及と標準化に関する活動を行っている。日 本国内においても，1996 年より可視化情報学会が中心 となり PIV 標準化のための研究活動を推進している ${ }^{199}$. これらの標準化に向けた活動については，本号の.PIV 研究会活動報告 ${ }^{20)}$ を参照されたい.

二番目は，現状では計測できない領域を拡充していく 方向，測定領域を拡大していく方向である。これは，3 次元 3 成分流速計測 ${ }^{211}$, 濃度などの他の物理量との同時 計測 ${ }^{222}$, 微小領域計测, 混相流計測, 時間力向への高解 像度化といった, 単純な 2 次元計測システムでは計測で きない情報を取得するための技術開発である ${ }^{1.3)}$.

3 番目の方向は, PIVで培われた画像取得, 画像解析 技術の他分野への応用である、これには，画像解析によ 
り流速以外の物理情報である界面移動検知や温度／密度 計測への応用などの他, 画像ベースの移動検知システム への応用が考えられる. 本稿では，この 3 番目の画像解 析応用技術について触れてみたい.

\section{4. 流速計測以外への PIV 技術応用}

PIV 技術は本来画像解析によって流速を算出する手法 であるが，流速計測以外への様々な応用がなされている. 例えば, Kawahashi ${ }^{23)}$ は密度分布計測へ適用を試みてい るし, 3 次元形状計測への応用を試みている研究者も居 る.ここでは, PIVで培われた画像解析技術を応用して, 流速以外の物理量を解析しょうとしている例の一つとし て, 岡本ら ${ }^{24)}$ の液面計測への応用について紹介する.

\section{1 液面計測}

元来, PIV はスペックルパターン解析から発展して来 た.このスペックルパターンの相互相関法解析を応用し, 液面形状を計測する ${ }^{24,25)}$. Fig. 5 に計測システムを示す. レーザを光ファイバーを通して照射すると, 光ファイ バー内の微小欠陥や多重散乱などの影響によって照射光 にはある程度のスペックルノイズが含まれている．この スペックルノイズを含んだレーザ光をレンズによって直 径 $10 \mathrm{~cm}$ 程度の平行光束とする. このレーザ光を液面 の下方から照明し, 液面の上方に設置したスクリーンに 投影すると，スペックルパターンを含んだ画像が投影さ れる. 液面上に波が生ずると気液界面によってレーザ光 が屈折され, スペックルパターンが変形する.このスペッ クルパターンの平行移動量を計測すれば, この移動量は 界面の傾きを表している. Fig. 5 に示す簡単な線形解析 によって, 平行移動量 $(\delta)$ と傾き $(\theta)$ との関係は

$$
\theta=\frac{\delta}{(n-1) L}
$$

と近似することができる. ここで, $n$ は液体の屈折率で あり $L$ は界面とスクリーンとの距離を表す.

Fig. 6 に本手法によって得られたスペックル画像の例 を示す. 波の無い画像と波のある画像を比較し, スペッ クルパターンの移動を計測する. 移動量計測には, PIV で良く用いられている相互相関法を適用する.この時, 計測精度を上げるためには, どうしてもサブピクセルの

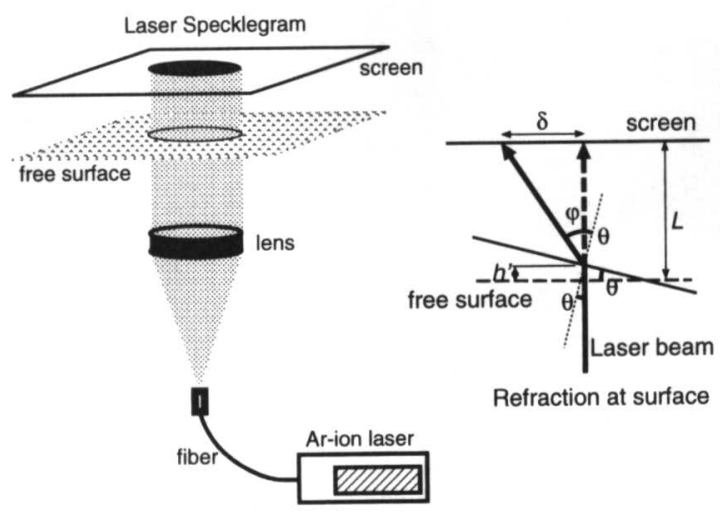

Fig. 5 Surface measurement configuration ${ }^{25)}$
情報を得ることが必須となる，そこで，PIVで培われた 相互相関法におけるサブピクセル精度の解析法をスペッ クルパターン解析に応用する. Fig. 6 右には, 相互相関 法によって得られた各注目点におけるスペックルパター ンの移動量ベクトルを示す.この 2 次元ベクトル $(\vec{\delta})$ に(3)式を適用することで界面上の任意点における傾きを 算出できる．あとは，この傾きデー夕を元に液面形状を 再構築する. Fig. 7 に液面下を流れる噴流により変形さ せられている液面を本手法によって計測した例を示す. 液面変化が定量的にとらえられ，2次元的な界面形状が 再構築されている事が判る.

スペックルパターン計測に，サブピクセル精度相互相 関法を導入することで, 界面形状を精度良く再構築でき る新しい計測手法を開発することができている.この様 に，PIV 技術によって開発がすすめられて来た画像解析 手法は，流速だけでなく様々な計測への応用が可能であ り，新しい展開の方向であると考えられる.

\section{5. まとめ}

レーザー技術や画像技術の格段の進展により，近い将 来誰でもが PIVを容易に使う事ができるようになるこ とと予感させる.ソフトウエアも進歩し, 高解像度の情 報が得られるようになってきた. しかし, 計測されたデー 夕の精度評価に関する手法の標準化はまだ緒についたば かりであり，早急な評価標準の制定が望まれる.

また，今後の展開の一つの方向として，PIV 技術の広 域分野への応用が挙げられる. 単なる流速計測技術では なく，様々な対象に応用されていくと考えられる.さら に，CFD とのハイブリッド化など，新しい PIV 技術の 芽が膨らんでいる。
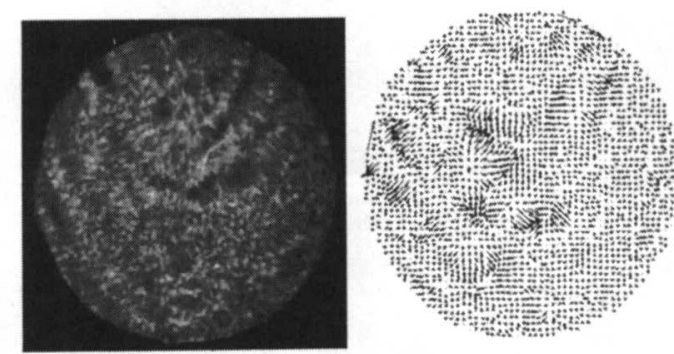

Fig. 6 Speckle and displacement ${ }^{25}$

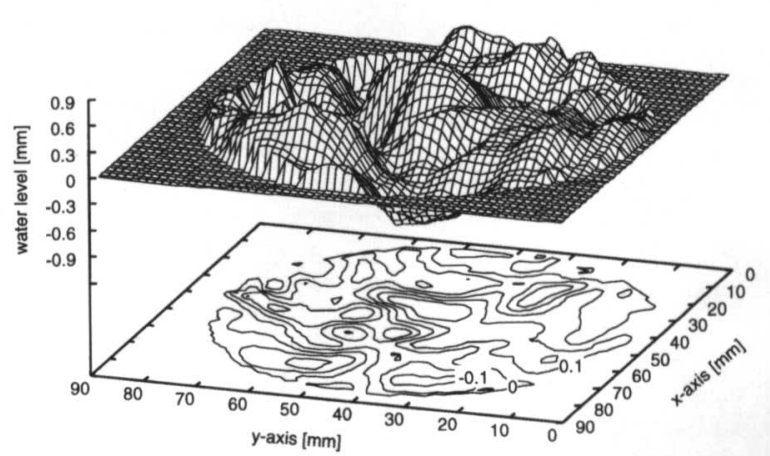

Fig. 7 Reconstructed surface height ${ }^{25)}$ 


\section{参考文献}

1）小林他, 「PIV の研究動向」，日本機械学会論文集 B, Vol. 65, No. 629 (1999), 8-14.

2）可視化情報学会編「流れの可視化ハンドブック」, 朝倉書店

3）可視化情報学会講習会テキスト,「実践集中講義：PIVの要点」 (1998)

4) Raffel, M., et al., Particle Image Velocimetry, (1998), Springer-verlag

5）角尾他，「家庭用デジタルVTR 规格，多様な放送を網羅(上)」, 日経エレクトロニクス No. 692, (1997), 141-153.

6）角尾他，「同上(下)」，日経エレタトロニクスNo.695，(1997), $127-137$.

7) Westerweel, J., Effect on sensor geometry on the performance of PIV interrogation. Proc.9th Int. Symp. on Appl. of Laser Techniques to Fluid Mechanics, Lisbon, (1998) 1.2.

8) Westerweel, J.,"Theoretical analysis of the measurement precision and reliability in PIV," Proc. 3rd Int. Workshop, PIV, (1999), 9-14.

9) Fincham, A., Delerce, G., "Advanced optimization of correlation imageing velocimetry algorithms," Proc. 3rd Int. Workshop, PIV, (1999), additional print

10) Lecordier, B., Lecordier, J.C., Trinité, M., "Iterative sub-pixel algorithm for the cross-correlation PIV measurements," Proc. 3 rd Int. Workshop, PIV, (1999), 37-43.

11) Hu H.他「Hierarchical Recursive PIV と噴流解析への応用」 日本機械学会流体工学部門講演会, No.517 (1999), 345-346

12) Quénot, G.M., et al.“Particle image velocimetry with optical flow," Experiment in Fluids, 25-3, (1998) 177-189.

13) Keane, R.D., et al.,"Super Resolition PIV," Meas Sci. Tech, 6 (1995) ;754-768.
14) Hart, D.P.." The elimination of correlation errors in PIV processing," Proc. 9 th Int. Symp. on Appl. of Laser Techniques to Fluid Mechanics, Lisbon, (1998) 13.3.

15) Lourenco, L.M., et al.,"Measurement of velocity field spectra by means of PIV," Proc. 9 th Int. Symp. on Appl. of Laser Techniques to Fluid Mechanics, Lisbon, (1998) 13.5.

16) Gui, L.,"Evaluation program for digital PIV," http://www.flow.uni-essen.de/ gui

17) Hart, D.P.;"Super-resolution PIV Processing Program," http ://web.mit.edu/dphart/www/Program.pdf

18) Kompenhans J., et al.,"International activities for cooperation, comparison and standarization at the developemnt and application of particle image velocimetry," Proc. 9 th Int. Symp. on Appl. of Laser Techniques to Fluid Mechanics, Lisbon, (1998) 13.6.

19) Okamoto, K., et al., Standard Images for Particle Imaging Velocimetry," Proc. PIV'97 Fukui, Fukui, (1997), 229-236.

20）小林他, 「PIV 実用化・標準化研究会報告」, 可視化情報, Vol. 20, No. 77, (2000), 172-175.

21）西野,「3 次元 PIV の実用化に向けて」, 可視化情報, Vol. 20, No. 77, (2000), 113-119.

22）新美，「可視化画像による物理量の複合計測」，可視化情報， Vol. 20, No. 77, (2000), 126-132.

23) Kawahashi, M.,"Velocity and density fields measurements by speckle technology," Proc. Korea-Japan Joint Seminar on PIV, (1999), 105-110.

24）岡本他,「スペックル法による自由夜面形状の計測」, 混相流 シンポジウム, (1998), 164-165

25) Tanaka, G., et al.,"Experimental investigation on interaction between polymer solution jet and free surface," Experiment in Fluids, (2000), in press 